\title{
Local and regional politicians' considerations of newly arrived migrants' health in political decision-making: a public health study in northern Sweden
}

\author{
Sara Svanholm ${ }^{1}$ (D) $\cdot$ Heidi Carlerby ${ }^{1} \cdot$ Eija Viitasara $^{1}$ \\ Received: 25 February 2021 / Accepted: 16 July 2021 \\ (C) The Author(s) 2021
}

\begin{abstract}
Background and aim Early action is important for promoting newly arrived migrants' health. Politicians are major actors in decision-making that affects health outcomes in the population. Therefore, the aim of this study was to explore local and regional politicians' considerations of newly arrived migrants' health in political decision-making: whether politicians reflect on or discuss the effects of decision-making specifically on newly arrived migrants' health, whether considerations differ between municipality and regional politicians, and how knowledge and attitudes are associated with such considerations.

Subject and methods A cross-sectional quantitative study was conducted. A total of 667 municipality and regional politicians from northern Sweden responded to a questionnaire developed based on interviews with politicians. Bivariate analyses were performed using $\chi^{2}$ tests, the independent samples $t$-test, and the Wilcoxon signed-rank test. Multivariate analysis was performed using binary logistic regression.

Results Politicians considered the effects on newly arrived migrants' health significantly less frequently than those on the total population's health. Regional politicians discussed such effects more often than municipality politicians. Knowledge (odds ratio $[\mathrm{OR}]=1.343)$, attitude $(\mathrm{OR}=5.962)$, previous experience working on public health issues $(\mathrm{OR}=1.784)$, and female gender $(\mathrm{OR}=1.787)$ were positively associated with considering effects on newly arrived migrants' health in decision-making.

Conclusion Politicians play important roles in health promotion, and most consider health-related effects in their decisionmaking. However, about a third do not consider such effects. General health-related knowledge and attitude are important factors that could be affected or changed during political assignments.
\end{abstract}

Keywords Cross-sectional study $\cdot$ Health promotion · Integration $\cdot$ Newly arrived migrants $\cdot$ Politicians $\cdot$ Questionnaire development

\section{Background}

Research shows a burden of both communicable and noncommunicable diseases on newly arrived migrants and refugees in Europe (Pavli and Maltezou 2017). Some health

Sara Svanholm

Sara.svanholm@miun.se

Heidi Carlerby

Heidi.carlerby@miun.se

Eija Viitasara

Eija.viitasara@miun.se

1 Department of Health Sciences, Mid Sweden University, Holmgatan 10, 85170 Sundsvall, Sweden disparities only become apparent after migrants have settled in European countries (Rechel et al. 2013). Migrants in Scandinavia have a higher risk of reporting ill health than the majority populations as early as 5 to 6 years after their arrival in the country of destination (Helgesson et al. 2019; Norredam et al. 2014). They also have a higher risk of unfavorable outcomes due to inequities in social determinants of health and variables such as income, employment conditions, housing quality, discrimination, and education level (Hollander 2013; Hynie 2018). Early health promotion aimed at migrants is therefore of particular importance (Norredam et al. 2014). Moreover, migrant integration policies are important for achieving health equity (Giannoni et al. 2016; Juárez et al. 2019).

In Sweden, migrants arriving as refugees or persons of subsidiary protection and their family members arriving 
through family reunification are considered newly arrived migrants for 2 years after they have received residence permits. During that time, they have the right to participate in integration activities. In these integration activities, municipalities are major actors, while regions are involved on a case-by-case basis (Government Offices of Sweden 2017). Integration activities mainly include civic orientation and language training but also other activities mainly aimed at promoting employability (Swedish Public Employment Service 2020).

Between 2014 and 2016, Sweden received more asylum seekers than usually. Since then, the numbers have dropped below the average of the last 2 decades (Swedish Migration Agency 2020a). During the design of this study in 2018, there were 52,547 asylum seekers waiting to have their claims assessed (Swedish Migration Agency 2019), and 42,014 former asylum seekers and individuals arriving through family reunification were granted residence permits (Swedish Migration Agency 2020b).

Northern Sweden comprises 44 municipalities and four regions. Common characteristics throughout this region are large but sparsely populated areas (Swedish Association of Local Authorities and Regions 2016) and close collaboration in public health-related issues (Norra sjukvårdsregionförbundet 2021). Another common characteristic throughout the area is that many municipalities have received relatively high numbers of asylum seekers and newly arrived migrants with respect to their population sizes (Swedish Migration Agency 2017).

Health is affected by several sectors other than the health care sector, e.g., the so-called social determinants of health, such as education and welfare (Dahlgren and Whitehead 2007; de Leeuw 2017). In the Swedish context, municipalities and regions play important roles. Municipalities' responsibilities include education, social welfare, housing, environmental and health protection, and community planning (Swedish Association of Local Authorities and Regions 2020a). Regions' main responsibility is the health care system and regional development. The two entities are jointly responsible for public transportation (Swedish Association of Local Authorities and Regions 2020c). Final decision-making in municipalities and regions is the authority of publicly elected politicians (Swedish Association of Local Authorities and Regions 2020b). The political context is therefore important in health promotion (Catford 2006; Greer et al. 2017; Sparks 2009).

The public health policy initiative of the World Health Organization (WHO) is aimed at placing health high on the agenda of policy-makers to create the conditions necessary to support health (WHO 1988). However, little research on politicians' role in health promotion has been conducted to date. Moreover, the focus has often been on priority setting and resource allocation (Garpenby and Nedlund 2016; Rosén et al. 2014) or on the implementation of evidence-based practice (Bäck et al. 2016). Although political ideology and political will have been suggested as important factors for achieving health equity (Bryant 2010), they have not been investigated as systematically as other health-promoting factors (Catford 2006). Therefore, the purpose of this study was to explore local and regional politicians' considerations of newly arrived migrants' health in political decision-making: whether politicians reflect on or discuss the effects of decision-making specifically on newly arrived migrants' health, whether considerations differ between municipality and regional politicians, and how knowledge and attitudes are associated with such considerations.

\section{Method}

A quantitative approach was adopted to study participants with diverse backgrounds. As no fitting questionnaire was identified, the decision to develop a new questionnaire was made. To capture the relevant constructs of politicians' role in health promotion, a subject with no conceptual basis, an inductive approach to item construction was chosen, with qualitative interviews as the first step (Hinkin 1998).

\section{Questionnaire development}

For the initial interviews, six politicians were randomly chosen from a list of available politicians in two municipalities. The politicians had been divided into pre-determined groups to facilitate the invitations to participate to be based on the aim to include participants with diverse backgrounds in terms of political party representation, representation from both majority and opposition parties, and gender representation. The included participants satisfied these criteria: four were female, and three were under the age of 45 years; their political experience ranged from four to more than 30 years, and they represented both majority and opposition parties and the entire political spectrum.

The interviews were semi-structured and followed an interview guide (see supplemental information - interview guide). The questions centered on the politicians' views on health and health promotion and on their roles, responsibility, and possibility to promote health. A dual focus on the general population and newly arrived migrants was adopted. The interviews lasted 20-62 min and were recorded using a smart phone and transcribed verbatim.

The data were analyzed using inductive (Patton 2015) manifest qualitative content analysis according to Graneheim and Lundman's (2004) description of the method. The data were divided into meaning units and coded. The codes were grouped into categories and subcategories. The categories, which later constituted the different parts of the questionnaire, were politicians' views on health and health promotion, 
affecting health as a politician, collaboration between actors, the politics of health, and municipality and regional organization and their prerequisites (see supplemental information qualitative results). A battery of self-rated questions were constructed from the categories and subcategories (Grant and Ferris 2012).

The final version of the questionnaire consisted of 49 items, all derived from the interview data and judged to be of relevance to the research projects' aims. Three of the questions were open-ended questions, and another three were aimed at clarifying open questions, offering respondents the opportunity to provide examples to illustrate their answers. Eight background questions related to age, gender, political affiliation, and political and public health experience were also added to the questionnaire. When a 5-point Likert scale was not fitting for an item, other logical answers discussed by the politicians in the interviews were used (such as having experience as a politician, other experience, or no experience).

To test the face validity of the final version, the previously interviewed politicians completed the questionnaire (Rattray and Jones 2007), thinking aloud as they proceeded (Streiner et al. 2015, p. 123). Minor adjustments to the instructions and wording were subsequently made. The questionnaire was then reviewed by experienced health promotion researchers (Rattray and Jones 2007). A few more minor adjustments were made.

\section{Data collection and participants}

The questionnaire was electronic and was emailed to politicians who were members of the 44 municipality councils or the four regional councils of northern Sweden. The politicians' email addresses were collected from the municipalities and regions. Politicians with seats in both municipality and regional councils were asked to choose one and respond to the questionnaire as such. The questionnaire was sent to a total of 2744 politicians and was open for 6 weeks during April-May 2019.

A total of 667 politicians (24.3\%) responded to the questionnaire and were included in the study. Their background characteristics are displayed in Table 1. For the analysis of nonresponse bias, official data on the ordinary members of municipality and regional councils were used (data were only available for ordinary members). In this study, alternates were also included and were listed with ordinary members. The nonresponse bias analysis was therefore performed by comparing both the included ordinary members and the total sample to the official data.

A comparison between the study participants and the total study population revealed significant differences in party representation $(p=0.028)$ and age groups $(p<0.001)$ but not in gender $(p=0.862)$ and municipality or regional council membership $(p=0.139)$. However, the effect sizes were small:
Table 1 Participants' background data

\begin{tabular}{|c|c|c|}
\hline & Frequency & Valid percentage \\
\hline \multicolumn{3}{|l|}{ Political affiliation } \\
\hline Left party & 80 & $12.0 \%$ \\
\hline Social Democrats & 251 & $37.6 \%$ \\
\hline Green party & 20 & $3.0 \%$ \\
\hline Centre party & 113 & $16.9 \%$ \\
\hline Liberals & 27 & $4.0 \%$ \\
\hline Moderate party & 65 & $9.7 \%$ \\
\hline Christian Democrats & 27 & $4.0 \%$ \\
\hline Sweden Democrats & 26 & $3.9 \%$ \\
\hline Feminist Initiative & 3 & $0.4 \%$ \\
\hline Other local parties & 53 & $7.9 \%$ \\
\hline \multicolumn{3}{|l|}{ Gender } \\
\hline Female & 307 & $46.3 \%$ \\
\hline Male & 356 & $53.7 \%$ \\
\hline \multicolumn{3}{|l|}{ Age } \\
\hline $18-24$ & 7 & $1.0 \%$ \\
\hline $25-34$ & 51 & $7.6 \%$ \\
\hline $35-44$ & 89 & $13.3 \%$ \\
\hline $45-54$ & 150 & $22.5 \%$ \\
\hline $55-64$ & 197 & $29.5 \%$ \\
\hline $65-74$ & 155 & $23.2 \%$ \\
\hline$\geq 75$ & 17 & $2.5 \%$ \\
\hline \multicolumn{3}{|l|}{ Council membership } \\
\hline Municipality & 546 & $83.3 \%$ \\
\hline Regional & 110 & $16.8 \%$ \\
\hline \multicolumn{3}{|c|}{ Number of inhabitants in municipality of residence } \\
\hline$<3000$ & 39 & $6 \%$ \\
\hline $3000-4999$ & 35 & $5.4 \%$ \\
\hline $5000-6499$ & 55 & $8.5 \%$ \\
\hline $6500-8999$ & 60 & $9.3 \%$ \\
\hline $9000-15,999$ & 129 & $19.9 \%$ \\
\hline $16,000-19,999$ & 70 & $10.8 \%$ \\
\hline $20,000-29,999$ & 57 & $8.8 \%$ \\
\hline $30,000-74,999$ & 112 & $17.3 \%$ \\
\hline$\geq 75,000$ & 90 & $13.9 \%$ \\
\hline
\end{tabular}

Cramér's $V$ was 0.093 for party representation and 0.110 for age group, indicating small differences between the groups. A post-hoc analysis of adjusted residuals showed that only a difference regarding the Sweden Democrats party was statistically significant (adjusted $Z=-3.30, \chi^{2}=10.89, p=$ 0.00097), and it was only significant for the entire sample and not between ordinary members, indicating that politicians from the Sweden Democrats party were underrepresented in the study in relation to their representation in municipalities and regions. A comparison between age groups showed that all age groups below 55 years were underrepresented and older age groups were overrepresented in the study. 
However, a post-hoc analysis showed no statistically significant differences in any age groups when analyzing the adjusted residuals.

\section{Quantitative data analysis}

The data extracted from the questionnaires (Table 2) were exported from Netigate to IBM SPSS Statistics 25 for statistical analysis. Univariate data were presented in frequencies and percentages. Bivariate analyses were performed using $\chi^{2}$ tests, the independent samples $t$-test, and the Wilcoxon signed-rank test. The significance level was set to $p<0.05$. For post-hoc analyses, Bonferroni adjustment was used for the $\alpha$ level (Pallant 2016, p. 240). To assess the effect size, Cramér's $V$ (Pallant 2016, pp. 221-222) and Cohen's coefficient were used (Cohen 1988, cited in Pallant 2016, p. 137).

For multivariate analyses, binary logistic regression was used to evaluate associations between predictor variables (knowledge, attitude, and general health-related knowledge) and outcome variables. Ordinal and categorical variables were dichotomized before entered into the analysis (Table 2). The analysis was performed in three steps of variable entry, and adjusted odds ratios (OR) and 95\% confidence intervals (CI) were calculated. Cox and Snell's $R^{2}$ and Nagelkerke's $R^{2}$ were calculated for the model explanation degree. Omnibus tests of model coefficients were performed for model and step significance. The Hosmer-Lemeshow test was used to evaluate the goodness of fit (Hosmer et al. 2013; Pallant 2016, pp. 169181).

Two indexes were created for the analysis. An index called General Health Knowledge was composed of five items measured on a 5-point Likert scale, which was reversed to where 1 represented fully disagree and 5 represented fully agree. The items included were "I consider myself to have enough knowledge to judge whether a political decision that I make affects the population's health," "I consider myself to have enough knowledge to judge how a political decision that I make affects the population's health," "I understand the differences between health promotion and disease prevention," "I understand the municipality's/region's responsibility for the population's health according to the new national public health political goals established in 2018," and "I consider myself to have a clear picture of the health status of the general population in the municipality/region where I am a politician." The index had a Cronbach's $\alpha$ of 0.741 and ranged from 1 to 18 , where 18 was the highest-rated knowledge.

The second index, Considering Health Effects (Cronbach's $\alpha=0.771$ ), was composed of two items: "In the last 3 months, have you, on your own, reflected on how political decisions that you make affect newly arrived migrants' health?" and "In the last 3 months, have you, in your council, discussed how decisions that you make affect newly arrived migrants' health?" The coding was $1=$ Yes, in a large proportion of the decisions, $2=$ Yes, a few times, and 3=No, yielding a range of 2-6. In the logistic regression analysis, the coding was expressed as $0=4-6$ (not considering health effects) and $1=2-3$ (considering health effects).

Exploratory Factor Analysis was then used to further explore the indexes. The variables were subjected to principal component analysis (PCA) and varimax rotation. The minimum factor loading was set to 0.5 . First, the suitability for a factor analysis was examined. The Kaiser-Meyer-Olkin measure of sampling adequacy was 0.764 and the Bartlett's test of sphericity was significant $(<.001)$, indicating a fit of using factor analysis (Pallant 2016, pp. 182-203). Two components with eigenvalues exceeding 1 was present, explaining $44.01 \%$ and $15.78 \%$ of variance respectively. In total, the two dimensions explained $59.79 \%$ of variance among the items in the study. The two factors identified in this exploratory factor analysis align with the assumptions made in the item and questionnaire construction. Factor 1 refers to the index named General Health Knowledge (including five items) and Factor 2 refers to the index named Considering Health Effects (including two items). Factor loadings are presented in Table 3.

\section{Results}

Of the 667 respondents, approximately $45 \%$ were under the age of 55 years, $46 \%$ were female, and $83 \%$ were municipality politicians (Table 1). The participants had diverse experience: approximately $60 \%$ had experience working on public health in some capacity, and $62 \%$ had experience working on integration. Seventy percent of the respondents had served one or more terms in their councils (Table 4).

Most respondents stated that they reflected on or discussed the effects of their decision-making on newly arrived migrants' health. In terms of discussing health effects, $13.7 \%$ did so in a large proportion of their decision-making, while $51.5 \%$ did so in a few decisions (Table 5). The reported frequency was significantly lower than that of discussions about the effects of politicians' decision-making on the general population's health $(z=-9.251, p<0.001, r=0.256)$. In terms of reflecting on the effects on newly arrived migrants' health, $29 \%$ of the respondents stated that they did so in a large proportion of their decision-making, 50.5\% reported that they did so in a few of their decisions, and $20.5 \%$ stated that they did not do so at all (Table 5). The frequency was significantly lower than that of reflections on the effects of decisionmaking on the general population's health $(z=-9.006$, $p<0.001, r=0.249$ ).

In terms of discussing health-related effects in decisionmaking, there was a statistically significant difference between municipality and regional politicians (Table 6). Significantly more regional than municipality politicians reported that discussions took place in regard to a large part of 
Table 2 Variables, index, and coding

\begin{tabular}{|c|c|c|c|}
\hline Variable & Questionnaire item & Coding & $\begin{array}{l}\text { Binary logistic regression } \\
\text { coding }\end{array}$ \\
\hline Reflection & $\begin{array}{l}\text { In the last } 3 \text { months, have you, on your own, } \\
\text { reflected on how political decisions that you make } \\
\text { affect newly arrived migrants' health? }\end{array}$ & $\begin{array}{l}1=\text { Yes, in a large part of the decisions; } 2=\text { Yes, a } \\
\text { few times; } 3=\text { No }\end{array}$ & \\
\hline Discussion & $\begin{array}{l}\text { In the last } 3 \text { months, have you, in your council, } \\
\text { discussed how decisions that you make affect } \\
\text { newly arrived migrants' health? }\end{array}$ & $\begin{array}{l}1=\text { Yes, in a large part of the decisions; } 2=\text { Yes, a } \\
\text { few times; } 3=\text { No }\end{array}$ & \\
\hline Knowledge & $\begin{array}{l}\text { I consider myself to have a clear picture of newly } \\
\text { arrived migrants' health status in the } \\
\text { municipality/region where I am a politician. }\end{array}$ & 5-point Likert scale ${ }^{\mathrm{a}}$ & $\begin{array}{l}0=3-5, \text { No knowledge; } \\
1=1-2, \text { Knowledge }\end{array}$ \\
\hline Attitudes & $\begin{array}{l}\text { Effects on newly arrived migrants' health are } \\
\text { important for how I make political decisions. }\end{array}$ & 5-point Likert scale ${ }^{a}$ & $\begin{array}{l}0=3-5, \text { Not important; } \\
1=1-2, \text { Important }\end{array}$ \\
\hline $\begin{array}{l}\text { Experience in } \\
\text { public } \\
\text { health issues }\end{array}$ & $\begin{array}{l}\text { Do you have previous experience working on public } \\
\text { health issues? }\end{array}$ & $\begin{array}{l}1=\text { Yes, as a politician; } 2=\text { Yes, in other capacity; } 3= \\
\text { No }\end{array}$ & $\begin{array}{l}0=3, \text { No experience; } \\
1=1-2, \text { Experience }\end{array}$ \\
\hline $\begin{array}{l}\text { Experience in } \\
\text { integration } \\
\text { issues }\end{array}$ & $\begin{array}{l}\text { Do you have previous experience working on } \\
\text { integration issues? }\end{array}$ & $\begin{array}{l}1=\text { Yes, as a politician; } 2=\text { Yes, in other capacity; } 3= \\
\text { No }\end{array}$ & $\begin{array}{l}0=3, \text { No experience; } \\
1=1-2, \text { Experience }\end{array}$ \\
\hline $\begin{array}{l}\text { Experience in } \\
\text { politics }\end{array}$ & $\begin{array}{l}\text { What is your previous experience as a politician in } \\
\text { the municipality/regional council? }\end{array}$ & $\begin{array}{l}1=\text { None, first term; } 2=\text { One term; } 3=\text { Two terms; } 4= \\
\text { Three or more terms }\end{array}$ & $\begin{array}{l}0=1-2, \text { Little experience; } \\
1=3-4, \text { Considerable } \\
\quad \text { experience }\end{array}$ \\
\hline $\begin{array}{l}\text { Interest in } \\
\text { public } \\
\text { health }\end{array}$ & $\begin{array}{l}\text { I am personally interested in public health as a } \\
\text { political issue. }\end{array}$ & 5-point Likert scale ${ }^{a}$ & $\begin{array}{l}0=3-5, \text { Not interested; } \\
1=1-2, \text { Interested }\end{array}$ \\
\hline $\begin{array}{l}\text { Interest in } \\
\text { integration }\end{array}$ & $\begin{array}{l}\text { I am personally interested in integration as a political } \\
\text { issue. }\end{array}$ & 5-point Likert scale ${ }^{a}$ & $\begin{array}{l}0=3-5, \text { Not interested; } \\
1=1-2, \text { Interested }\end{array}$ \\
\hline Age & Age? & $\begin{aligned} 1=18-24 ; 2 & =25-34 ; 3=35-44 ; 4=45-54 ; 5= \\
55-64 ; 6 & =65-74 ; 7=\geq 75\end{aligned}$ & $\begin{array}{l}0=1-4,<55 \text { years; } \\
1=5-7, \geq 55 \text { years }\end{array}$ \\
\hline $\begin{array}{l}\text { Population in } \\
\text { municipality } \\
\text { of residence }\end{array}$ & $\begin{array}{l}\text { How many inhabitants are there in the municipality } \\
\text { in which you live? }\end{array}$ & $\begin{array}{l}1=<3 \quad 000 ; 2=3000-4999 ; 3=5000-6499 ; 4= \\
\quad 6500-8999 ; 5=9000-15,999 ; 6= \\
\quad 16,000-19,999 ; 7=20,000-29,999 ; 8= \\
30,000-74,999 ; 9=\geq 75,000\end{array}$ & $\begin{array}{l}0=1-7,<30,000 \\
1=8-9, \geq 30,000\end{array}$ \\
\hline $\begin{array}{l}\text { Council } \\
\text { membership }\end{array}$ & What is your current political role/assignment? & $\begin{array}{l}1=\text { Ordinary member of municipality council; } 2= \\
\text { Alternate municipality council; } 3=\text { Ordinary } \\
\text { member of regional council; } 4=\text { Alternate } \\
\text { regional council }\end{array}$ & $\begin{array}{l}0=3-4, \text { Municipality } \\
\text { politician; } \\
1=1-2, \text { Regional politician }\end{array}$ \\
\hline Gender & What gender do you identify with? & $1=$ Female; $2=$ Male; $3=$ Other & $\begin{array}{l}0=2, \text { Male; } \\
1=1, \text { Female }\end{array}$ \\
\hline
\end{tabular}

${ }^{\mathrm{a}} 1=$ fully agree, $2=$ partly agree, $3=$ neither agree nor disagree, $4=$ partly disagree, $5=$ fully disagree

their decision-making ( $p=0.01$, Cramér's $\mathrm{V}=0.12$ ). Conversely, no statistically significant difference was found in terms of reflecting on such effects $(p=0.383)$.

Approximately half of the respondents stated that they had knowledge of newly arrived migrants' health status ("knowledge"), and approximately four out of five stated that the effects of their decisions on newly arrived migrants' health were important for their decision-making ("attitude"). Significant differences in self-rated knowledge and attitude were observed between politicians who considered health-related effects and those who did not (both $p<0.001$ ). A significant difference was also found in terms of reported general health-related knowledge: politicians who considered effects on newly arrived migrants' health had a significantly higher level of reported general health-related knowledge (mean score $=14.41)$ than those who did not (mean score $=12.12 \pm$ $0.19 ; t(633)=-11.72, p<0.001)$.

Individually, all three variables [knowledge of newly arrived migrants' health status ( $\mathrm{OR}=3.75,95 \%$ CI: 2.589 5.441), attitude ( $\mathrm{OR}=12.353,95 \% \mathrm{CI}: 4.956-30.794)$, and general health-related knowledge $(\mathrm{OR}=1.504,95 \% \mathrm{CI}$ : 1.372-1.647)] were significantly associated with considering effects on newly arrived migrants' health (Table 7). However, when modeled together, only attitude $(\mathrm{OR}=7.488,95 \% \mathrm{CI}$ : 2.630-21.316) and general health-related knowledge (OR = $1.425,95 \%$ CI: $1.276-1.592$ ) remained significantly associated. Their significance remained when controlling first for previous experience (in public health, integration, and politics) 
Table 3 Exploratory Factor Analysis results

\begin{tabular}{lll}
\hline Items & Factor & Factor \\
& 1 & 2 \\
\hline
\end{tabular}

General Health Knowledge

I consider myself to have enough knowledge to judge whether a political decision that I make affects the population's health

I consider myself to have enough knowledge to judge how a political decision that I make $\quad .782$ affects the population's health

I understand the differences between health promotion and disease prevention .603

I understand the municipality's/region's responsibility for the population's health according $\quad .522$ to the new national public health political goals established in 2018

I consider myself to have a clear picture of the health status of the general population in the $\quad .629$ municipality/region where I am a politician

Considering Health Effects

In the last 3 months, have you, on your own, reflected on how political decisions that you make affect newly arrived migrants' health?

In the last 3 months, have you, in your council, discussed how decisions that you make affect newly arrived migrants' health?

Extraction method: principal component analysis. Rotation method: Varimax with Kaiser normalization. Rotation converged in three iterations and then for personal characteristics (gender, age, population in municipality of residence, and municipality/regional council membership). The final model $\left(\chi^{2}=152.691[\mathrm{df}=12\right.$, $p<0.001]$ ) explained approximately 23-33\% (Cox and Snell's $R^{2}=0.233$; Nagelkerke's $R^{2}=0.332$ ) and showed that attitude was the most significant factor for considering effects on newly arrived migrants' health $(\mathrm{OR}=5.962$, 95\% CI: 2.021-17.587). General healthrelated knowledge also remained significant $(\mathrm{OR}=$ 1.343, 95\% CI: 1.198-1.506). Female gender $(\mathrm{OR}=$ $1.787,95 \% \mathrm{CI}: 1.170-2.731)$ and experience working on public health issues as a politician or in another
Table 4 Participants' characteristics

\begin{tabular}{lll}
\hline & Frequency & Valid percentage \\
\hline Experience working on public health & & \\
Experience as a politician & 180 & $27.5 \%$ \\
Experience in another capacity & 136 & $12.8 \%$ \\
Experience both as a politician and in other capacities & 74 & $11.3 \%$ \\
No experience & 265 & $40.5 \%$ \\
Experience working on integration & & \\
Experience as a politician & 180 & $27.5 \%$ \\
Experience in another capacity & 160 & $24.4 \%$ \\
Experience both as a politician and in other capacities & 67 & $10.2 \%$ \\
No experience & 248 & $37.9 \%$ \\
Interest in public health & & \\
Not interested & 131 & $19.9 \%$ \\
Interested & 526 & $80.1 \%$ \\
Interest in integration & & \\
Not interested & 122 & $18.6 \%$ \\
Interested & 534 & $81.4 \%$ \\
Experience in the council & & $30.3 \%$ \\
None, first term & 202 & $18.5 \%$ \\
One term & 123 & $15.5 \%$ \\
Two terms & 100 & $36.2 \%$ \\
Three or more terms & 241 & \\
\hline
\end{tabular}


Table 5 Reported frequencies of discussing and reflecting on the effects of respondents' decisionmaking on the health of newly arrived migrants and the general population

\begin{tabular}{llll}
\hline & & Newly arrived migrants & Population \\
\hline Discussing effects on health $^{\mathrm{a}}$ & Yes, a large proportion & $89(13.7 \%)$ & $141(21.7 \%)$ \\
& Yes, a few times & $335(51.5 \%)$ & $380(58.4 \%)$ \\
& No & $227(34.9 \%)$ & $130(20 \%)$ \\
& Total & $651(100 \%)$ & $651(100 \%)$ \\
Reflecting on effects on health $^{\mathrm{b}}$ & Yes, a large proportion & $188(29 \%)$ & $269(41.1 \%)$ \\
& Yes, a few times & $328(50.5 \%)$ & $314(48 \%)$ \\
& No & $133(20.5 \%)$ & $71(10.9 \%)$ \\
& Total & $649(100 \%)$ & $654(100 \%)$ \\
\hline
\end{tabular}

Differences between newly arrived migrants and the general population were assessed using the Wilcoxon signedrank test

${ }^{\mathrm{a}} z=-9.251, p<0.001, r=0.256$

${ }^{\mathrm{b}} \mathrm{z}=-9.006, p<0.001, r=0.249$ capacity $(\mathrm{OR}=1.784,95 \% \mathrm{CI}: 1.060-3.004)$ were also significant factors.

\section{Discussion}

In exploring politicians' decision-making, this study found that politicians more often reflected on and discussed effects on the general population's health than on newly arrived migrants' health. Regional politicians discussed effects on newly arrived migrants' health more often than municipality politicians, but there was no significant difference in reflecting on such effects. Politicians' attitudes and general health-related knowledge were found to be significant factors for considering health-related effects in decision-making, whereas specific knowledge of newly arrived migrants' health was not. Being female and having previous experience working on public health issues were also significant factors.

Since the regions are responsible for health care (Swedish Association of Local Authorities and Regions 2020c), it may not seem surprising that regional politicians reflect on and discuss health-related effects more often than municipality politicians. However, municipalities have several responsibilities closely associated with health, such as education, housing, city planning, and care for elderly people and people in assisted living (Swedish Association of Local Authorities and Regions 2020a). As significant differences were found only in the frequency of discussing health-related effects in respondents' councils, this may indicate a lack of official structures promoting discussions on health-related effects at the municipal level, suggesting that such considerations are limited to individual reflections. Research on Norwegian municipalities has shown that in health promotion, political leadership is needed on all administrative levels (Hofstad 2016). Therefore, this is an area where improvement is needed.

This study suggests that when politicians do consider health-related effects, they do so more often with respect to the general population than newly arrived migrants specifically. Previous research suggests that it is necessary for politicians to consider population subgroups. Frohlich and Potvin (2008) note that in addition to general population approaches, a focus on vulnerable groups is a necessary complement for addressing inequities. The authors define vulnerable groups as "groups who, because of their position in the social strata, are
Table 6 Cross-tabulation with $\chi^{2}$ tests evaluating differences in considering the effects of decision-making on newly arrived migrants' health between municipality and regional politicians

\begin{tabular}{cllll}
\hline & & Municipality & Regional & Total \\
\hline $\begin{array}{c}\text { Discussing effects on newly } \\
\text { arrived migrants' health }^{\mathrm{a}}\end{array}$ & Yes, a large proportion & $63(11.8 \%)$ & $24(22.2 \%)$ & $87(13.6 \%)$ \\
& Yes, a few times & $274(51.5 \%)$ & $54(50.0 \%)$ & $328(51.2 \%)$ \\
& No & $195(36.7 \%)$ & $30(27.8 \%)$ & $225(35.2 \%)$ \\
& Total & $532(100 \%)$ & $108(100 \%)$ & $640(100 \%)$ \\
Reflecting on effects on newly $_{\text {arrived migrants' health }}{ }^{\mathrm{b}}$ & Yes, a large proportion & $145(27.5 \%)$ & $37(33.6 \%)$ & $182(28.6 \%)$ \\
& Yes, a few times & $273(51.7 \%)$ & $50(45.5 \%)$ & $323(50.6 \%)$ \\
& No & $110(20.8 \%)$ & $23(20.9 \%)$ & $133(20.8 \%)$ \\
& Total & $528(100 \%)$ & $110(100 \%)$ & $638(100 \%)$ \\
\hline
\end{tabular}

The differences in each variable between municipality and regional politicians were evaluated using $\chi^{2}$ tests

${ }^{\mathrm{a}} \chi^{2}=9.167(\mathrm{df}=2), p=0.01$

${ }^{\mathrm{b}} \chi^{2}=1.919(d f=2), p=0.383$ 
Table 7 Logistic regression analysis of the predictors of considering effects on newly arrived migrants' health in decision-making

\begin{tabular}{|c|c|c|c|c|c|c|c|c|c|c|c|c|}
\hline \multirow[t]{3}{*}{ Variable } & \multicolumn{3}{|l|}{ Crude $^{\mathrm{a}}$} & \multicolumn{3}{|l|}{ Step $1^{\mathrm{b}}$} & \multicolumn{3}{|l|}{ Step $2^{\mathrm{c}}$} & \multicolumn{3}{|l|}{ Step $3^{\mathrm{d}}$} \\
\hline & \multirow[b]{2}{*}{ OR } & \multicolumn{2}{|c|}{$\begin{array}{l}\text { 95\% CI for Exp } \\
\text { (B) }\end{array}$} & \multirow[b]{2}{*}{ OR } & \multicolumn{2}{|c|}{$\begin{array}{l}95 \% \text { CI for Exp } \\
\text { (B) }\end{array}$} & \multirow[b]{2}{*}{ OR } & \multicolumn{2}{|c|}{$\begin{array}{l}95 \% \text { CI for Exp } \\
\text { (B) }\end{array}$} & \multirow[b]{2}{*}{ OR } & \multicolumn{2}{|c|}{$\begin{array}{l}95 \% \text { CI for Exp } \\
\text { (B) }\end{array}$} \\
\hline & & Lower & Upper & & Lower & Upper & & Lower & Upper & & Lower & Upper \\
\hline Knowledge & $3.75^{*}$ & 2.59 & 5.44 & 1.513 & 0.963 & 2.378 & 1.401 & 0.876 & 2.239 & 1.463 & 0.907 & 2.359 \\
\hline Attitude & $12.35^{*}$ & 4.96 & 30.79 & $7.488 *$ & 2.630 & 21.316 & $5.837 *$ & 2.001 & 17.025 & $5.962 *$ & 2.021 & 17.587 \\
\hline General health knowledge & $1.50 *$ & 1.37 & 1.65 & $1.425 *$ & 1.276 & 1.592 & $1.373 *$ & 1.226 & 1.539 & $1.343 *$ & 1.198 & 1.506 \\
\hline Interest in public health & & & & & & & 1.848 & 0.805 & 4.241 & 1.885 & 0.804 & 4.421 \\
\hline Interest in integration & & & & & & & 1.146 & 0.508 & 2.585 & 1.021 & 0.446 & 2.336 \\
\hline Experience in public health issues & & & & & & & $1.696^{*}$ & 1.023 & 2.810 & $1.784 *$ & 1.060 & 3.004 \\
\hline Experience in integration issues & & & & & & & 1.197 & 0.725 & 1.976 & 1.211 & 0.725 & 2.022 \\
\hline Experience in politics & & & & & & & 0.846 & 0.552 & 1.297 & 0.811 & 0.515 & 1.277 \\
\hline Gender & & & & & & & & & & $1.787^{*}$ & 1.170 & 2.731 \\
\hline Age & & & & & & & & & & 1.557 & 0.994 & 2.438 \\
\hline Population in municipality of residence & & & & & & & & & & 0.902 & 0.451 & 1.806 \\
\hline Council membership & & & & & & & & & & 1.199 & 0.687 & 2.092 \\
\hline
\end{tabular}

$1.696^{\mathrm{a}}$ Correct classification $=70.9 \%$

${ }^{\mathrm{b}}$ Omnibus test of model coefficients model $\chi^{2}=131.628$ (degrees of freedom $[\mathrm{df}]=3, p<0.001$ ). Cox and Snell's $R^{2}=0.204$; Nagelkerke's $R^{2}=$ 0.291 ; Hosmer-Lemeshow $\chi^{2}=8.089(\mathrm{df}=7, p=0.325)$. Correct classifications $=74.4 \%$

${ }^{\mathrm{c}}$ Omnibus test of the coefficients model $\chi^{2}=142.204(\mathrm{df}=8, p<0.001)$, step $\chi^{2}=10.576(\mathrm{df}=5, p=0.060)$. Cox and Snell's $R^{2}=0.218$; Nagelkerke's $R^{2}=0.312$; Hosmer-Lemeshow $\chi^{2}=7.971(\mathrm{df}=8, p=0.436)$. Correct classifications $=75.4 \%$

${ }^{\mathrm{d}}$ Omnibus test of the coefficients model $\chi^{2}=152.691(\mathrm{df}=12, p<0.001)$, step $\chi^{2}=10.487(\mathrm{df}=4, p=0.033)$. Cox and Snell's $R^{2}=0.233$; Nagelkerke's $R^{2}=0.332$; Hosmer-Lemeshow $\chi^{2}=4.130(\mathrm{df}=8, p=0.845)$. Correct classifications $=75.4 \%$

CI confidence interval; OR odds ratio

* indicates statistical significance

commonly exposed to contextual conditions that distinguish them from the rest of the population" (Frohlich and Potvin 2008, p. 218). Migrants are at risk of facing health-related inequities, as well as inequities in many social determinants of health (Helgesson et al. 2019; Hollander 2013; Hynie 2018; Norredam et al. 2014; Public Health Agency of Sweden 2019; Rechel et al. 2013). This makes them a vulnerable group, necessitating a specific focus on the part of politicians. A focus on health specifically in migration and integration policies is important for health equity outcomes (Giannoni et al. 2016; Juárez et al. 2019).

The results of this study also indicate that general healthrelated knowledge is a more important factor for considering effects on newly arrived migrants' health than specific knowledge of migrants' health. Similarly, previous experience working on public health issues is more important than experience working on integration. This suggests that although slightly more respondents reported a personal interest in integration, it is public health rather than the migration track that contributes to the consideration of effects on newly arrived migrants' health. A study in New Zealand reported that a personal interest is an important factor for politicians' active involvement in health promotion (Zalmanovitch and Cohen
2015). Conversely, in the current study, while experience working on public health issues was a significant factor for considering health-related effects, a personal interest was not.

In line with this study, previous research has shown that both knowledge and attitudes are important for practices and behaviors. A study on Swedish local politicians' views on their role in the implementation of evidenced-based practice in social care in municipalities found that a personal interest and knowledge were important for how they viewed their roles and what actions they took (Bäck et al. 2016). A study on municipalities in Finland in the 1990s questioned the association between politicians' attitudes and outcomes in priority setting and resource allocation within health care (Lammintakanen and Kinnunen 2004). Overall, political will is important for achieving health equity (Bryant 2010). Nevertheless, Swedish regional politicians have been shown to consider their influence on decision-making rather weak in comparison to that of other actors, such as administrators and physicians (Rosén et al. 2014).

In this study, gender was found to be an important factor for considering effects on newly arrived migrants' health in political decision-making. This is in line with Campbell and Winters (2008), who showed that women tend to be interested 
in so-called domestic politics (such as health care and education) more often than men. Similar patterns can be identified in female politicians' areas of responsibilities as ministers: they often work on issues related to social care, education, and health care (Bergqvist et al. 2008, pp. 37-38). To eliminate such gender-based differences, it is important to raise awareness of the fact that female politicians consider newly arrived migrants' health in their decision-making more often than male politicians.

\section{Limitations}

As a questionnaire appropriate for investigating politicians' views on their roles in health promotion could not be identified, a new questionnaire was developed for the purposes of this study. Since the questionnaire is new and no similar questionnaires were found, a point-by-point comparison of this study's results to those of other studies is not possible. To ensure a thorough understanding of the respondents' answers, several open-ended questions and opportunities to clarify answers were offered in the questionnaire. None of the free-text answers indicated that respondents misunderstood the questions.

Research suggests that electoral success is an important motive for politicians and political parties. To that end, taking credit for success and avoiding blame for mistakes are important (Greer et al. 2017). Therefore, socially desirable responses to questionnaire items cannot be ruled out (Streiner et al. 2015, pp. 106-111). To minimize the possibility of such bias, the general population and newly arrived migrants were not juxtaposed in the same questions but were queried in separate questions. Although the initial interviews indicated no significant tendency toward socially desirable responding, the responses to the questionnaire were mostly positively skewed, which is common in social science research (Streiner et al. 2015, pp. 106-111). This also shows that the questionnaire requires further refinement to ensure that it can capture nuances and variance in politicians' responses (Hinkin 1998).

Although politicians are easy to reach due to their public position, the interview participants cited a constant lack of time, and reported frequently receiving invitations for surveys in which they felt that they did not have the time to participate. Due to this risk of a low response rate, which is a known problem in health research (Galea and Tracy 2007), a decision was made to include all possible respondents in the study sample. This would ensure enough responses to allow statistical analyses even if the response rate was low. Although previous research has indicated that a low response rate does not necessarily increase nonresponse bias (Hendra and Hill 2018), since the questionnaire concerned health and migration there was a risk that politicians with a special interest in either or both of these would respond, and politicians with no particular interest would not, which could result in bias. In light of these limitations, caution is required in any attempt to generalize the results.

\section{Conclusions}

This study shows that although politicians state that they consider health-related effects in their decision-making, they do so to a lesser degree for newly arrived migrants than for the general population. Regional politicians tend to consider effects on newly arrived migrants' health more often than municipality politicians. A higher self-rated level of general knowledge of health and a reported interest in newly arrived migrants' health are also important factors for politicians' considerations in decision-making. Both are factors that could be affected or changed during political assignments. On the other hand, it is not possible to affect other factors, such as gender and previous experience working on public health issues; it is, however, possible to raise awareness of such factors.

Supplementary Information The online version contains supplementary material available at https://doi.org/10.1007/s10389-021-01637-4.

Authors' contributions All authors contributed to the study conception and design. Material preparation, data collection, and analysis were performed by Sara Svanholm. The first draft of the manuscript was written by Sara Svanholm, and all authors commented on previous versions of the manuscript. All authors read and approved the final manuscript.

Funding Open access funding provided by Mid Sweden University.

Availability of data and material Upon request, the authors can send relevant data in order to verify the validity of the results presented. Such requests should be sent to the corresponding author.

Code availability Not applicable

\section{Declarations}

Ethics approval This study and its components were designed in accordance with the ethical standards of the Swedish National Research Committee (Swedish Research Council 2017) and the 1964 Helsinki Declaration and its later amendments. The Ethics Committee of Mid Sweden University approved the initial interviews for the questionnaire development (MIUN 2018/6) and the full study (MIUN 2019/6). All participants were informed of the aim of the study and the intent to publish its results, and were assured that confidentiality would be safeguarded.

Consent to participate and publish Informed consent was obtained from all individual participants included in the study. 
Conflicts of interest/competing interests The authors have no conflicts of interest to declare that are relevant to the content of this article.

Open Access This article is licensed under a Creative Commons Attribution 4.0 International License, which permits use, sharing, adaptation, distribution and reproduction in any medium or format, as long as you give appropriate credit to the original author(s) and the source, provide a link to the Creative Commons licence, and indicate if changes were made. The images or other third party material in this article are included in the article's Creative Commons licence, unless indicated otherwise in a credit line to the material. If material is not included in the article's Creative Commons licence and your intended use is not permitted by statutory regulation or exceeds the permitted use, you will need to obtain permission directly from the copyright holder. To view a copy of this licence, visit http://creativecommons.org/licenses/by/4.0/.

\section{References}

Bergqvist C, Adman P, Jungar A-C (2008) Kön och politik. SNS Studieförbundet Näringsliv och Samhälle

Bryant T (2010) Promoting health equity through political action. Soc Alternatives 29(2):57-63

Bäck A, Ståhl C, von Thiele Schwarz U, Richter A, Hasson H (2016) Walking the tightrope-perspectives on local politicians' role in implementing a national social care policy on evidence-based practice. Int J Ment Health Syst 10:75

Campbell R, Winters K (2008) Understanding men's and women's political interests: evidence from a study of gendered political attitudes. J Elect Public Opin Parties 18(1):53-74. https://doi.org/10.1080/ 17457280701858623

Catford J (2006) Creating political will: moving from the science to the art of health promotion. Health Promot Int 21(1):1-4

Dahlgren G, Whitehead M (2007) Policies and strategies to promote social equity in health - background document to WHO strategy paper for Europe (I. f. F. Studies Ed.). Institute for Future Studies, Stockholm

de Leeuw E (2017) Engagement of sectors other than health in integrated health governance, policy, and action. Annu Rev Public Health 38: 329-349. https://doi.org/10.1146/annurev-publhealth-031816044309

Frohlich KL, Potvin L (2008) Transcending the known in public health practice: the inequality paradox: the population approach and vulnerable populations. Am J Public Health 98(2):216-221. https://doi. org/10.2105/AJPH.2007.114777

Galea S, Tracy M (2007) Participation rates in epidemiologic studies. Ann Epidemiol 17(9):643-653. https://doi.org/10.1016/j. annepidem.2007.03.013

Garpenby P, Nedlund AC (2016) Political strategies in difficult times the "backstage" experience of Swedish politicians on formal priority setting in healthcare. Soc Sci Med 163:63-70. https://doi.org/10. 1016/j.socscimed.2016.06.046

Giannoni M, Franzini L, Masiero G (2016) Migrant integration policies and health inequalities in Europe. BMC Public Health 16(1):463. https://doi.org/10.1186/s12889-016-3095-9

Government Offices of Sweden (2017) Ordinance (2017:584) about responsibility for establishment activities for certain newly arrived immigrants. Government Offices of Sweden, Stockholm. https:// www.riksdagen.se/sv/dokument-lagar/dokument/svenskforfattning ssamling/lag-2017584-om-ansvar-foretableringsinsatser_sfs-2017-584 Accessed 12 December 2019

Graneheim UH, Lundman B (2004) Qualitative content analysis in nursing research: concepts, procedures and measures to achieve trustworthiness. Nurse Educ Today 24(2):105-112. https://doi.org/ 10.1016/j.nedt.2003.10.001

Grant S, Ferris K (2012) Identifying sources of occupational stress in entrepreneurs for measurement. Int J Entrepreneurial Ventur 4(4): 351-373. https://doi.org/10.1504/IJEV.2012.049828

Greer SL, Bekker M, de Leeuw E, Wismar M, Helderman JK, Ribeiro S, Stuckler D (2017) Policy, politics and public health. Eur J Pub Health 27(suppl_4):40-43. https://doi.org/10.1093/eurpub/ckx152

Helgesson M, Johansson B, Nordquist T, Vingård E, Svartengren M (2019) Healthy migrant effect in the Swedish context: a registerbased, longitudinal cohort study. BMJ Open 9(3):e026972. https:// doi.org/10.1136/bmjopen-2018-026972

Hendra R, Hill A (2018) Rethinking response rates: new evidence of little relationship between survey response rates and nonresponse bias. Eval Rev 43(5):307-330. https://doi.org/10.1177/ $0193841 X 18807719$

Hinkin TR (1998) A brief tutorial on the development of measures for use in survey questionnaires. Organ Res Methods 1(1):104-121

Hofstad H (2016) The ambition of health in all policies in Norway: the role of political leadership and bureaucratic change. Health Policy 120(5):567-575. https://doi.org/10.1016/j.healthpol.2016.03.001

Hollander AC (2013) Social inequalities in mental health and mortality among refugees and other immigrants to Sweden - epidemiological studies of register data. Glob Health Action 6:1-11. https://doi.org/ 10.3402/gha.v6i0.21059

Hosmer DW, Lemeshow S, Sturdivant RX (2013) Applied logistic regression (3. edition. ed.). Hoboken, NJ: Wiley

Hynie M (2018) The social determinants of refugee mental health in the post-migration context: a critical review. Can J Psychiatr 63(5):297303. https://doi.org/10.1177/0706743717746666

Juárez SP, Honkaniemi H, Dunlavy AC, Aldridge RW, Barreto ML, Katikireddi SV, Rostila M (2019) Effects of non-health-targeted policies on migrant health: a systematic review and meta-analysis. Lancet Glob Health 7(4):420-435. https://doi.org/10.1016/S2214109X(18)30560-6

Lammintakanen J, Kinnunen J (2004) Social and health-care priorities of local politicians in Finland: do the attitudes of politicians reflect the actual processes in municipalities? Int J Soc Welf 13(1):69-76

Norredam M, Agyemang C, Hoejbjerg Hansen OK, Petersen JH, Byberg S, Krasnik A, Kunst AE (2014) Duration of residence and disease occurrence among refugees and family reunited immigrants: test of the 'healthy migrant effect' hypothesis. Tropical Med Int Health 19(8):958-967. https://doi.org/10.1111/tmi.12340

Norra sjukvårdsregionförbundet (2021) Folkhälsa [public health], Umeå. . https://wwwnorrasjukvardsregionforbundetse/folkhalsa/ Accessed 11 January 2021

Pallant J (2016) SPSS survival manual. McGraw-Hill Education, London

Patton M (2015) Qualitative research \& evaluation methods, 4th edn. Sage Publications, Newbury Park

Pavli A, Maltezou H (2017) Health problems of newly arrived migrants and refugees in Europe. J Travel Med 24(4):tax016. https://doi.org/ $10.1093 / \mathrm{jtm} / \operatorname{tax} 016$

Swedish Public Employment Service (2020) The establishment programme. https://arbetsformedlingense/other-languages/englishengelska/stod-och-ersattning/att-delta-i-program/ etableringsprogrammet Accessed 11 January 2021

Public Health Agency of Sweden (2019) Health, socioeconomic, and lifestyle factors among foreign born individuals in Sweden. Public Health Agency of Sweden, Stockholm

Rattray J, Jones MC (2007) Essential elements of questionnaire design and development. J Clin Nurs 16(2):234-243. https://doi.org/10. 1111/j.1365-2702.2006.01573.x

Rechel B, Mladovsky P, Ingleby D, Mackenbach JP, McKee M (2013) Migration and health in an increasingly diverse Europe. Lancet 381(9873):1235-1245. https://doi.org/10.1016/S0140-6736(12) 62086-8 
Rosén P, De Fine LJ, Ohlsson H (2014) Priority setting in Swedish health care: are the politicians ready? Scand J Public Health 42(3):227234. https://doi.org/10.1177/1403494813520355

Sparks M (2009) Acting on the social determinants of health: health promotion needs to get more political. Health Promot Int 24(3): 199-202

Streiner DL, Norman GR, Cairney J (2015) Health measurement scales - a practical guide to their development and use, 5th edn. Oxford University Press, Oxford

Swedish Association of Local Authorities and Regions (2016) Classification of Swedish municipalities 2017. SALAR, Stockholm

Swedish Association of Local Authorities and Regions (2020a) Kommunernas åtaganden [The municipalities' responsibilities]. SALAR, Stockholm. https://skr.se/tjanster/kommunerochregioner/ faktakommunerochregioner/kommunernasataganden.3683.html Accessed 11 January 2021

Swedish Association of Local Authorities and Regions (2020b) Local self-government. SALAR, Stockholmhttps://skrse/tjanster/ e n g l is h page s/mun i c i palities andregions/ localselfgovernment1305html Accessed 11 January 2021

Swedish Association of Local Authorities and Regions (2020c) Regionernas åtaganden [the regions' responsibilities]. SALAR, Stockholmhttps://skrse/tjanster/kommunerochregioner/ faktakommunerochregioner/regionernasataganden $27748 \mathrm{html}$ Accessed 11 January 2021

Swedish Migration Agency (2017) Statistik [statistics]. Swedish Migration Agency, Norrköping. https://wwwmigrationsverketse/ Om-Migrationsverket/Statistikhtml Accessed 11 January 2021

Swedish Migration Agency (2019) Personer Boende i Migrationsverkets mottagningssystem [individuals living in the Swedish Migration
Agency's arrival system]. Swedish Migration Agency, Norrköping. h t t p s://w w w m igrations verketse/download/ $184 \mathrm{cb} 46070161462 \mathrm{db} 113177 / 1546509782898 /$ Inskrivna personer_i_Migrationsverkets_mottagningssystempdf Accessed 11 January 2021

Swedish Migration Agency (2020a) Asylsökande till Sverige 2000-2019 [Asylum seekers to Sweden 2000-2019]. Swedish Migration Agency, Norrköping. https://wwwmigrationsverketse/download/ 182b2a286016dabb81a1854ef/1594819419165/Beviljade\% 20uppeh\%C3\%A51lstillst\%C3\%A5nd\%202009-2019pdf 2020-1018 Accessed 11 January 2021

Swedish Migration Agency (2020b) Beviljande uppehållstillstånd efter grund 2009-2019 [Approved residence permits per reason 20092019]. Swedish Migration Agency, Norrköping. https://www. migrationsverket.se/download/18.2b2a286016dabb81a1854ef/ 1594819419165/Beviljade\%20uppeh\%C3\%A51lstillst\%C3\% A5nd\%202009-2019.pdf Accessed 11 January 2021

Swedish Research Council (2017) Good research practice. Swedish Research Council, Stockholm

WHO (1988) Adelaide Recommendations on Healthy Public Policy. WHO, Geneva. https://www.who.int/healthpromotion/conferences/ previous/adelaide/en/index1.html: Accessed 17 June 2020

Zalmanovitch Y, Cohen N (2015) The pursuit of political will: politicians' motivation and health promotion. Int J Health Plann Mgmt 30:31-44

Publisher's note Springer Nature remains neutral with regard to jurisdictional claims in published maps and institutional affiliations. 